\title{
Epidemiological characterization and risk factors associated with Mycobacterium avium subsp. paratuberculosis infection in dairy goats in the Brazilian semiarid region
}

\author{
Caracterização epidemiológica e fatores de risco associados à \\ infecção por Mycobacterium avium subsp. paratuberculosis em \\ caprinos leiteiros no semiárido brasileiro
}

\author{
Theonys Diógenes Freitas ${ }^{1}$; Sérgio Santos de Azevedo²; \\ Maria Luana Cristiny Rodrigues Silva'; Felício Garino Júnior²; \\ Carolina de Sousa Américo Batista Santos ${ }^{3}$; Inácio José Clementino; \\ Franklin Riet-Correa Amaral'; Clebert José Alves $^{2 *}$
}

\begin{abstract}
The aim of this investigation was to conduct an epidemiological study and identify risk factors associated with the occurrence of paratuberculosis (Johne's disease) in dairy goats within the semiarid region of Paraíba State. The study was done during the period of March 2009 to July 2011, during which 727 female goats from 86 flocks from the city of Monteiro, Paraíba were investigated. For the serological diagnosis of Mycobacterium avium subsp. paratuberculosis (Map) infection indirect ELISA tests (screening and confirmatory) were performed. Of the 727 animals used six $(0.82 \%)$ were seropositive at the confirmatory test after screening, and of the 86 flocks six (6.97\%) presented at least one seropositive animal. In positive flocks the frequency of reactive animals ranged from $5.26 \%$ to $16.60 \%$. Risk factors identified were production system (weaning and reproduction) (odds ratio $=36.0 ; 95 \% \mathrm{CI}=2.6-486.1$; $\mathrm{p}<0,001$ ) and absence of technical infrastructure (odds ratio $=54.0 ; 95 \% \mathrm{CI}=4.5-642.9 ; \mathrm{p}<0,001$ ). It was concluded that Mycobacterium avium subsp. paratuberculosis is present in dairy goat flocks in the region; however, its influence on decrease productivity as well as the risk of transmission to humans through animal products must totally evaluated. Based on the analysis of risk factors, improvements are recommended for the technical infrastructure and the management of breeding goats.

Palavras-chave: Mycobacterium avium subsp. paratuberculosis, small ruminants, epidemiology, control
\end{abstract}

\section{Resumo}

O presente trabalho teve como objetivo realizar um inquérito soroepidemiológico e identificar fatores de risco associados à ocorrência de paratuberculose (doença de Johne) em caprinos leiteiros na região semiárida do Estado da Paraíba. Foram utilizadas 727 fêmeas caprinas provenientes de 86 propriedades do município de Monteiro-PB, no período de março de 2009 a julho de 2011. Para o diagnóstico sorológico

\footnotetext{
1 Discentes do Curso de Doutorado, Programa de Pós-Graduação em Medicina Veterinária, Universidade Federal de Campina Grande, UFCG, Patos, PB, Brasil. E-mail: theonysfreitas@hotmail.com; luacristiny@yahoo.com.br; clementinoij@yahoo.com.br

2 Profs., do Programa de Pós-Graduação em Medicina Veterinária, UFCG, Patos, PB, Brasil. E-mail: pulga.garino@uol.com.br; sergio.azevedo@pq.cnpq.br; riet@cstr.ufcg.edu.br; clebertja@uol.com.br

3 Pós-Doutoranda do Programa de Pós-Graduação em Medicina Veterinária, UFCG, Patos, PB, Brasil. E-mail: carolamerico@ yahoo.com.br

* Author for correspondence
} 
da infecção pelo Mycobacterium avium subsp. paratuberculosis (Map) foram utilizados dois testes de ELISA indireto (triagem e confirmatório). Dos 727 animais utilizados, seis $(0,82 \%)$ foram soropositivos no teste confirmatório após a triagem, e das 86 propriedades seis $(6,97 \%)$ apresentaram pelo menos um animal soropositivo. Nas propriedades positivas a frequência de animais reagentes variou de $5,26 \%$ a $16,60 \%$. Os fatores de risco identificados foram tipo de criação (recria e reprodução) (odds ratio $=36,0$; IC 95\% = 2,6 -486,1; $\mathrm{p}<0,001$ ) e ausência de tecnificação (odds ratio $=54,0 ; \mathrm{IC} 95 \%=4,5-642,9 ; \mathrm{p}$ $<0,001)$. Conclui-se que o Mycobacterium avium subsp. paratuberculosis está presente em rebanhos de caprinos leiteiros da região, porém, sua influência na diminuição da produtividade assim como o risco de transmissão para humanos através dos produtos de origem animal devem ser objetos de estudos posteriores. Com base na análise de fatores de risco recomenda-se melhorias no nível de tecnificação das propriedades bem como no manejo do sistema de exploração das matrizes caprinas.

Palavras-chave: Mycobacterium avium subsp. paratuberculosis, pequenos ruminantes, epidemiologia, controle

\section{Introduction}

Paratuberculosis, also known as Johne's disease, is a chronic infectious disease caused by Mycobacterium avium subsp. paratuberculosis (MAP) occurring in multiple regions across the world. It primarily affects domestic ruminants and at lower frequency, wild ruminants, horses, swine, hare, fox, and rodents (RAIZMAN et al., 2005; MORAVKOVA et al., 2008; MOTA et al., 2010). In Brazil, paratuberculosis was induced experimentally in goats by Poester and Ramos (1994), and Oliveira et al. (2010) diagnosed the condition for the first time based on clinical and anatomopathological findings in two goatherds in Paraíba.

The disease is transmitted by the ingestion of food and water contaminated by feces from animals shedding the microorganism, as well as contaminated colostrum and milk; intrauterine transmission may also occur (MANNING et al., 2007). In goats, the main route of transmission is fecal-oral, and young animals are primarily affected, though the disease may not manifest clinically until months or years later. Nonetheless, infected animals generate an immune response and intermittingly shed the agent into the environment (STERMAN, 1996). Clinical disease usually manifests in animals over one year old (CLARKE, 1997) and is primarily characterized by progressive emaciation, with or without diarrhea, which differs from the presentation in cattle, which is characterized clinically by diarrhea (KUMAR et al., 2007; SINGH et al., 2007).
It was previously believed that the occurrence of Johne's disease in Brazilian herds was linked to the importation of animals from endemic areas; however, this is not the only factor in its dissemination because the infection has been detected at properties with no history of importation (DRIEMEIER et al., 1999). This raises epidemiological concerns, as it is not known exactly how these herds were infected, and it is not known which factors are responsible for maintaining the organism in the environment.

The goal of this study was to determine the prevalence of positive properties (outbreaks) and the frequency of seropositive dairy goats infected with Mycobacterium avium subsp. paratuberculosis (MAP) in the Brazilian semiarid region, as well as to identify risk factors of infection using a sampling plan.

\section{Material and Methods}

This study was conducted in the municipality

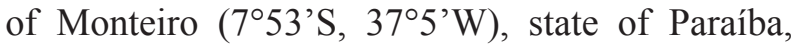
Brazil. The state is divided in four mesoregions: Sertão Paraibano, Borborema, Agreste Paraibano, and Mata Paraibana, and further divided into 23 microregions. The municipality of Monteiro is located in the Borborema mesoregion and within the Cariri Ocidental microregion. Monteiro is bordered on the north by the municipality of Prata, on the south by the municipalities of São Sebastião do Umbuzeiro and Zabelê, in the east by the 
municipalities of Camalaú and Sumé, and in the west by the municipalities of Sertânia, Iguaraci, and Tuparetama, state of Pernambuco. The region has a semiarid climate with a mean temperature of $22^{\circ} \mathrm{C}$. The altitude is 599 meters above sea level. The municipality is known for its goat milk production in both the state of Paraíba and in Brazil. It has the largest effective number of goats in the state at 25,200 animals (IBGE, 2011).

Properties were surveyed by simple random sampling based on the table provided by the Centro de Desenvolvimento Integrado da Caprinovinocultura da Paraíba (CENDOV). The number of sampled properties was calculated with the EpiInfo version 6.04 program using the following parameters: $20 \%$ of expected prevalence of positive properties (LEE et al., 2006), 95\% confidence level, and 10\% absolute error. Based on the formula for simple random samples (THRUSFIELD, 1995) and the 155 registered properties of dairy goats in the region (CENDOV), 61 properties participated.

The number of goats to be sampled was determined individually for each herd using the following formula (THRUSFIELD, 1995):

$$
n=\left[1-(1-p)^{\frac{1}{d}}\right] \times\left(N-\frac{d}{2}\right)+1
$$

Where:

$\mathrm{n}=$ sample size;

$\mathrm{p}=$ probability of finding at least one seropositive animal;

$\mathrm{N}=$ size of the herd;

$\mathrm{d}=$ number of seropositive animals in the herd.

The probability of finding at least one seropositive animal in the herd was determined at a 95\% confidence level $(p=0.95)$, and the number of seropositive animals per herd (d) was calculated assuming a $10 \%$ intra-herd prevalence (LEE et al., 2006).

In total, 727 goats from 86 properties were sampled. Ten (10) $\mathrm{mL}$ of blood was collected from the jugular vein into vacuum tubes. The samples were centrifuged and the sera stored at $-20^{\circ} \mathrm{C}$ until serological analysis by ELISA.

At the time of blood collection, an epidemiological questionnaire was administered at each property in order to detect possible risk factors associated with the occurrence of infection at the herd level. Information concerning 29 variables were collected: raising goats as the main activity at the property; the production system; type of farm; purpose of the farm; number of lactating does; daily milk production; size of the herd; presence of cattle, horses, pigs, birds, and wild animals; presence of toxic plants; availability of veterinary care; whether animals were purchased; nutrition (native pasture); presence of a production center; mineral supplementation; presence of a food room; presence of technical infrastructure (electricity, mechanical milking, cooling tank, etc.); presence of flooded pastures; presence of rodents; use of deworming; maternity pens; use of quarantine; separation of animals by age; disinfection of facilities; cutting and disinfection of the navel; and isolation of sick animals. The questionnaire data were input into an electronic form created using the Microsoft Access ${ }^{\circledR}$ program and subjected to an analysis for risk factors.

Two ELISA tests were used for the serological diagnosis of MAP infection. Goats were initially screened using the ID Screen ${ }^{\circledR}$ Paratuberculosis Indirect Screening kit, and in animals that tested positive, the diagnosis was confirmed using the ID Screen ${ }^{\circledR}$ Paratuberculosis Indirect Confirmation Test kit. Both methods were performed according to the manufacturer's recommendations and following guidelines of the World Organization for Animal Health (OIE, 2008).

The risk factors were analyzed by univariate and multivariate analysis. The univariate analysis was performed using the Chi-square test or Fisher's exact test (ZAR, 1999), and variables with a $\mathrm{p} \leq$ 0.20 were then subjected to multivariate analysis using the forward stepwise logistic regression method (HOSMER; LEMESHOW, 2000). 
Statistical significance on the multivariate analysis was set at $5 \%$. The fitting of the final model was verified with the Hosmer-Lemeshow test, and a $p \geq 0.05$ indicated a satisfactory fitting. The collinearity between the independent variables was evaluated using correlation analysis, and when two variables were strongly correlated (correlation coefficient $>0.90$ ), only one variable was included in the multivariate analysis according to biological plausibility (DOHOO et al., 1996). All tests were conducted using the program SPSS for Windows, version 20.0.

\section{Results and Discussion}

In Brazil, data on theincidence of paratuberculosis in goatherds are scarce, which highlights the need for epidemiological studies to verify the prevalence in herds and identify factors that may contribute to the spread of infection. Serological analysis revealed that $0.82 \%$ (six) animals were seropositive. Of the 86 sampled properties, $6.97 \%$ (six) had at least one animal positive for MAP. Among the properties considered positive, the frequency of positive animals varied between 5.26 and 16.6\% (Table 1).

Table 1. Frequency of seropositivity for Mycobacterium avium subsp. paratuberculosis in the semiarid region of Paraíba, Brazil from March 2009 to July 2011.

\begin{tabular}{ccc}
\hline Property & No. of animals examined & Positive animals (\%) \\
\hline 39 & 9 & $1(11.10 \%)$ \\
51 & 11 & $1(9.09 \%)$ \\
57 & 6 & $1(16.60 \%)$ \\
61 & 10 & $1(10.00 \%)$ \\
77 & 11 & $1(9.09 \%)$ \\
81 & 19 & $1(5.26 \%)$ \\
\hline
\end{tabular}

These results indicate that the agent is present in goatherds in the Paraíba region. In several previous studies, the frequency of seropositivity varied. In India, Singh et al. (2010), using ELISA, detected positivity in $57.1 \%$ of goats evaluated, a result very different from the presenting finding. By contrast, Mendes et al. (2004) reported seropositivity between $1.0-8.9 \%$ in Portugal. In Chile, the frequency found by Salgado, Kruze and Collins (2007) was 14.6\%, and in Korea, Lee et al. (2006) reported varying frequencies ranging from $4.6 \%$ to $38.2 \%$ among several regions. Recently, Pithua and Kollias (2012) estimated the prevalence of paratuberculosis at $1.9 \%$ in goats and $2.0 \%$ in properties in an endemic area in the United States of America, values close to those observed in this study. Mercier et al. (2010), working with dairy goats in France, estimated a prevalence ranging from $2.9 \%$ to $6.0 \%$ of individual animals and $55.2 \%$ of herds. The differing frequency of positive results among earlier studies and the present study reflects the sensitivity and specificity of the ELISA test, which can vary according to the herd, stage of infection, the specific commercial kit employed, and epidemiological characteristics such as the type of rearing, production, and capacity rate. Molina, Morera and Lanes (1991), using ELISA on goat populations with different prevalences in Spain, reported an $88 \%$ sensitivity in a group of goats confirmed positive on histopathology and culture, and a $94 \%$ specificity in a group of healthy animals confirmed negative on culture. The test performance is also affected by the disease prevalence and severity of clinical signs. According to Manning et al. (2007), the presence of caseous lymphadenitis in herds can decrease the specificity of ELISA when used to diagnose paratuberculosis; this factor should be taken into account because caseous lymphadenitis occurs widely throughout the Northeast region of Brazil. ELISA can show high sensitivity, approximately $75 \%$, when the infection 
is in the clinical or terminal phase. However, during the initial or latent stages, the sensitivity is low, at approximately 15\% (TIMMS et al., 2011; YAMASAKI et al., 2013).

In the analysis for risk factors, the variables in the univariate analysis with a $\mathrm{p} \leq 0.20$ were as follows (Table 2): type of farm, presence of horses, nutrition, presence of a food room, technical infrastructure, presence of flooded pastures, and cutting and disinfection of the navel. In the multivariate analysis, the following risk factors were identified
(Table 3): farm for fattening or breeding (odds ratio $=36.0 ; 95 \% \mathrm{CI}=2.6-486.1 ; \mathrm{p}<0.001)$ and lack of technical infrastructure (odds ratio $=54.0 ; 95 \% \mathrm{CI}$ =4.5-642.9; $\mathrm{p}<0.001$ ). The final model showed a proper fitting (Hosmer-Lemeshow test: $\mathrm{p}=1,000$ ). The high odds ratios for these risk factors may not reflect the actual risk but likely reflect the small number of positive properties $(n=6)$. Regardless, both variables were statistically significant $(p<$ $0.05 ; 95 \% \mathrm{CI}$ of the odds ratio, excluding the value $1)$.

Table 2. Univariate analysis of risk factors associated with Mycobacterium avium subsp. paratuberculosis infection in goats in the semiarid region of Paraíba, Brazil from March 2009 to July 2011.

\begin{tabular}{|c|c|c|c|}
\hline Variable & $\begin{array}{c}\text { Total number of } \\
\text { properties }\end{array}$ & $\begin{array}{l}\text { No. of positive } \\
\text { properties }(\%)\end{array}$ & $\mathbf{p}$ \\
\hline \multicolumn{4}{|c|}{ Raising goats is the primary activity on the property } \\
\hline No & 31 & $2(6.5)$ & \\
\hline Yes & 55 & $4(7.3)$ & 1.000 \\
\hline \multicolumn{4}{|l|}{ Production system } \\
\hline Intensive & 1 & $0(0.0)$ & \\
\hline Semi-intensive & 78 & $5(6.4)$ & \\
\hline Extensive & 7 & $1(14.3)$ & 0.708 \\
\hline \multicolumn{4}{|l|}{ Type of farm } \\
\hline Rearing & 80 & $4(5)$ & \\
\hline Fattening/breeding & 6 & $2(33.3)$ & $0.054^{*}$ \\
\hline \multicolumn{4}{|l|}{ Purpose of farm } \\
\hline Meat/Mixed & 6 & $0(0.0)$ & \\
\hline Milk & 80 & $6(7.5)$ & 1.000 \\
\hline \multicolumn{4}{|l|}{ No. of lactating goats } \\
\hline Up to 14 animals & 45 & $3(6.7)$ & \\
\hline$>14$ animals & 41 & $3(7.3)$ & 1.000 \\
\hline \multicolumn{4}{|l|}{ Daily milk production } \\
\hline Up to 14 liters & 43 & $3(42.0)$ & \\
\hline$>14$ liters & 43 & $3(55.9)$ & 1.000 \\
\hline \multicolumn{4}{|l|}{ Size of the herd } \\
\hline Up to 25 animals & 43 & $3(7.0)$ & \\
\hline$>25$ animals & 43 & $3(7.0)$ & 1.000 \\
\hline \multicolumn{4}{|l|}{ Presence of cattle } \\
\hline No & 26 & $3(11.5)$ & \\
\hline Yes & 60 & $3(5.0)$ & 0.361 \\
\hline \multicolumn{4}{|l|}{ Presence of horses } \\
\hline No & 66 & $3(4.5)$ & \\
\hline Yes & 20 & $3(15.0)$ & $0.135^{*}$ \\
\hline
\end{tabular}


continuação

Presence of pigs

No

Yes

Presence of birds

No

Yes

Presence of wild animals

No

Yes

Presence of toxic plants

No

Yes

Veterinary care available

$$
\text { No }
$$

Yes

Purchase of animals

$$
\text { No }
$$

Yes

Nutrition (native pasture)

No

Yes

Has a production center

No

Yes

Mineral supplementation

No

Yes

Own food room

No

Yes

Use of technology

No

Yes

Presence of flooded pasture

No

Yes

Presence of rodents

No

Yes

Performs deworming

No

Yes

Maternity pens

No

Yes

Performs quarantine

$$
\begin{aligned}
& \text { No } \\
& \text { Yes }
\end{aligned}
$$

60

26

21

65

58

28

68

18

80

6

85

1

2

84

62

24

34

52

57

29

7

79

74

12

33

53

6

80

78

8

75

11
$5(8.3)$

$1(3.8)$

0.663

$1(4.8)$

$5(7.7)$

1.000

4 (6.9)

$2(7.1)$

0.386

4 (5.9)

2 (11.1)

0.601

$6(100.0)$

$0(0.0)$

1.000

$5(8.5)$

1 (3.7)

0.660

$1(50.0)$

5 (6.0)

$0.135^{*}$

4 (6.5)

$2(8.3)$

0.670

2 (5.9)

4 (7.7)

1.000

$6(10.5)$

$0(0.0)$

0.093*

3 (42.9)

3 (3.8)

$0.006^{*}$

$4(5.4)$

2 (16.7)

$0.195 *$

$3(9.1)$

3 (5.7)

0.671

$0(0.0)$

$6(7.5)$

1.000

$6(7.7)$

$0(0.0)$

1.000

5 (6.7)

$1(9.1)$
0.572

continua 
continuação

Separation of animals by age

No 41

$3(7.3)$

Yes

$3(6.7)$

1.000

Cleans the facilities with disinfectants

No

$42 \quad 4(9.5)$

Yes

Performs cutting and disinfection of the navel

No

$57 \quad 6(10.5)$

Yes $\quad 29$

$0(0.0)$

$0.930 *$

Isolation of sick animals

No $\quad 50$

$5(10.0)$

Yes

$1(2.8)$

0.394

*Selected variables used in the multiple logistic regression $(\mathrm{p} \leq 0.20)$.

Table 3. Risk factors associated with Mycobacterium avium subsp. paratuberculosis (MAP) infection in goats from the semiarid region of Paraíba, Brazil from March 2009 to July 2011 estimated by multiple logistic regression.

\begin{tabular}{lccc}
\hline Risk factors & Odds ratio & $\mathbf{9 5 \%}$ CI & p \\
\hline Farm for fattening/breeding & 36.0 & $2.6-486.1$ & $<0.001$ \\
Lack of technical infrastructure & 54.0 & $4.5-642.9$ & $<0.001$ \\
\hline
\end{tabular}

$C I=$ confidence interval.

Although the primary route of paratuberculosis transmission in goats is fecal-oral (STERMAN, 1996), in properties dedicated to fattening and breeding, intrauterine or colostrum transmission is also important and can contribute to the occurrence and maintenance of the agent in herds. In this study, the lack of technical infrastructure was associated with a higher incidence of positive properties. Electricity, milking equipment, cooling of the milk, and artificial insemination are variables frequently employed to indicate the use of technical infrastructure of rural properties (CHATE et al., 2009). The presence of these practices and infrastructure estimates whether the property incorporates technology and the most appropriate techniques and health practices; conversely, their absence can significantly influence the maintenance of the agent on the property.

MAP represents a great challenge for veterinary medicine and especially for ruminant production.
Control measures for paratuberculosis in the Paraíba region should be guided by two strategies. The first is to change the management of affected properties with the goal of decreasing transmission. In properties with a history of the disease, this may include separation of the goat kids soon after birth, replacement of colostrum, and improvements in hygiene practices. The second recommended strategy includes measures such as: acquisition of animals from controlled properties, and testing and slaughtering infected animals in order to eliminate possible sources of infection. The latter measure is limited by the low availability of diagnostic laboratories in Brazil, the cost of testing, and the difficulty of herd replacement. In addition, these measures may not yield any immediate effects, and consequently, are readily abandoned by the owners and unlikely to be implemented in the region. 


\section{Conclusions}

Mycobacterium avium subsp. paratuberculosis infection is present in dairy goat herds from the semiarid Paraíba, and based on the analysis of risk factors, improvements are recommended in the technical infrastructure and in the management of breeding goats. Additional studies are needed to identify and quantify the influence of infection on reduced productivity, as well as the risk of bacterial transmission to humans through animal products.

\section{References}

CHATE, S. C.; DIAS, R. A.; AMAKU, M.; FERREIRA, F.; MORAES, G. M.; COSTA NETO, A. A.; MONTEIRO, L. A. R. C.; LÔBO, J. R.; FIGUEIREDO, V. C. F.; GONÇALVES, V. S. P.; FERREIRA NETO, J. S. Situação epidemiológica da brucelose bovina no Estado do Mato Grosso do Sul. Arquivo Brasileiro de Medicina Veterinária e Zootecnia, Belo Horizonte, v. 61, p. 46-55, 2009. Suplemento 1.

CLARKE, C. J. The pathology and pathogenesis of paratuberculosis in ruminants and other species: a review. Journal of Comparative Pathology, New York, v. 116, n. 3, p. 217-261, 1997.

DOHOO, I. R.; DUCROC, C.; FOURICHON, C.; DONALD, A.; HURNIK, D. An overview of techniques for dealing with large numbers of independent variables in epidemiologic studies. Preventive Veterinary Medicine, New York, v. 29, n. 3, p. 221-239, 1996.

DRIEMEIER, D.; CRUZ, C. E. F.; GOMES, M. J. P.; CORBELLINI, L. G.; LORETTI, A. P.; COLODELE, M. Aspectos clínicos e patológicos da paratuberculose em bovinos no Rio Grande do Sul. Pesquisa Veterinária Brasileira, Rio de Janeiro, v. 19, n. 3-4, p. 109-115, 1999.

HOSMER, D. W.; LEMESHOW, S. Applied logistic regression. New York: John Wiley \& Sons, 2000. 373 p.

INSTITUTO BRASILEIRO DE GEOGRAFIA E ESTATÍSTICA - IBGE. Sistema IBGE de recuperação automática - SIDRA, Pesquisa da Pecuária Municipal. Rio de Janeiro: IBGE, 2011. Disponível em: <http:// www.ibge.gov.br/cidadesat/topwindow.htm?1>. Acesso em: 8 maio 2013.

KUMAR, P.; SINGH, S. V.; BHATIYA, A. K.; SEVILLA, I.; SINGH, A. V.; WHITTINGTON, R. J.; JUSTE, R. A.; GUPTA, V. K..; SINGH, P. K.; SOHAL, J. S.; VIHAN, V. S. Juvenile capri-paratuberculosis (JCP) in India: incidence and characterization by six diagnostic tests.
Small Ruminant Research, Amsterdam, v. 73, n. 1, p. 4553, 2007.

LEE, K. W.; JUNG, B. Y.; MOON, O. K.; YANG, D. K.; LEE, S. H.; KIM, J. Y.; KWEON, C. H. Seroprevalence of Mycobacterium avium subspecies paratuberculosis in Korean Black Goats (Capra hircus aegagrus). Journal of Veterinary Medical Science, Tokyo, v. 68, n. 12, p. 13791381, 2006.

MANNING, J. B. E.; CUSHING, H. F.; HIETALA, S.; WOLF, C. B. Impact of Corynebacterium pseudotuberculosis infection on serologic surveillance for Johne's disease in goats. Journal of Veterinary Diagnostic Investigation, Davis, v. 19, n. 2, p. 187-190, 2007.

MENDES, S.; BOINAS, F.; ALBUQUERQUE, T.; FERNANDES, L.; AFONSO, A.; AMADO, A. Epidemiological studies on paratuberculosis in small ruminants in Portugal. Épidémiologie et Santé Animale, Alfort, n. 45, p. 61-71, 2004.

MERCIER, P.; BAUDRY, C.; BEAUDEAU, F.; SEEGERS, H.; MALHER, X. Estimated prevalence of Mycobacterium avium subspecies paratuberculosis infection in herds of dairy goats in France. Veterinary Record, London, v. 167, n. 11, p. 412-415, 2010.

MOLINA, A.; MORERA, L.; LANES, D. Enzyme-linked immunosorbent assay for detection of antibodies against Mycobacterium paratuberculosis in goats. American Journal of Veterinary Research, Chicago, v. 52, n. 6, p. 863-868, 1991.

MORAVKOVA, M.; HLOZEK, P.; BERAN, V.; PAVLIK, I.; PREZIUSO, S.; CUTERI, V.; BARTOS, M. Strategy for the detection and differentiation of Mycobacterium avium species in isolates and heavily infected tissues. Research in Veterinary Science, Oxford, v. 85, n. 2, p. 257-264, 2008.

MOTA, R. A.; PEIXOTO, P. V.; YAMASAKI, E. M.; MEDEIROS, E. S.; COSTA, M. M.; PEIXOTO, R. M.; BRITO, M. F. Ocorrência de paratuberculose em búfalos (Bubalus bubalis) em Pernambuco. Pesquisa Veterinária Brasileira, Seropédica, v. 30, n. 3, p. 237-242, 2010.

OLIVEIRA, D. M.; RIET-CORREA, F.; GALIZA, G. J. N.; ASSIS, A. C. O.; BANDARA, P. M.; GARINO JÚNIOR, F. Paratuberculose em caprinos e ovinos no Brasil. Pesquisa Veterinária Brasileira, Seropédica, v. 30, n. 1, p. 67-72, 2010.

PITHUA, P.; KOLLIAS, N. S. Estimated prevalence of caprine paratuberculosis in Boer goat herds in Missouri, USA. Veterinary Medicine International, New York, v. 2012, n. 1, p. 1-5, 2012. 
POESTER, F. P.; RAMOS, E. T. Infecção experimental em caprinos com Mycobacterium paratuberculosis de origem bovina. Ciência Rural, Santa Maria, v. 24, n. 2, p. 333-337, 1994.

RAIZMAN, E. A.; WELLS, S. J.; JORDAN, P. A.; DELGIUDICE, G. D.; BEY, R. R. Mycobacterium avium subsp. paratuberculosis from free ranging deer and rabbits surrounding Minnesota dairy herds. Canadian Journal of Veterinary Research, Ottawa, v. 69, n. 1, p. 32-38, 2005.

SALGADO, M.; KRUZE, J.; COLLINS, M. T. Diagnosis of paratuberculosis by fecal culture and ELISA on milk and serum samples in two types of Chilean dairy goat herds. Journal of Veterinary Diagnostic Investigation, Davis, v. 19, n. 1, p. 99-102, 2007.

SINGH, P. K.; SINGH, S. V.; KUMAR, H.; SOHAL, J. S.; SINGH, A. V. Diagnostic application of IS900 PCR using blood as a source sample for the detection of Mycobacterium avium subspecies paratuberculosis in early subclinical cases of caprine paratuberculosis. Veterinary Medicine International, New York, v. 2010, n. 1, p. 1-8, 2010.

SINGH, S. V.; SINGH, A. V.; SINGH, P. K.; GUPTA, V. K.; KUMAR, S.; VOHRA, J. Sero-prevalence of paratuberculosis in young kids using 'Bison type', Mycobacterium avium subsp. Paratuberculosis antigen in plate ELISA. Small Ruminant Research, Amsterdam, v. 70, n. 2, p. 89-92, 2007.
STERMAN, S. M. Paratuberculosis in small ru minants, deer, and South American camelids. The Veterinary Clinics of North America. Food Animal Practice, New York, v. 12, n. 2, p. 441-445, 1996.

THRUSFIELD, M. Veterinary epidemiology. $2^{\text {th }}$ ed. Cambridge: Blackwell Science, 1995. 479 p.

TIMMS, V. J.; GEHRINGER, M. M.; MITCHELL, H. M.; DASKALOPOULOS, G.; NEILAN, B. A. How accurately can we detect Mycobacterium avium subsp. paratuberculosis infection? Journal of Microbiological Methods, New York, v. 85, n. 1, p. 1-8, 2011.

WORLD ORGANIZATION FOR ANIMAL HEALTH - OIE. Manual of standards for diagnostic tests and vaccines for terrestrial animals. Paratuberculosis (Johne's disease). Paris: OIE, 2008. Available at: $<$ http://www.oie. int/eng/normes/mmanual>. Accessed at: 27 nov. 2011.

YAMASAKI, E. M.; BRITO, M. F.; MOTA, R. A.; McINTOSH, D.; TOKARNIA, C. H. Paratuberculose em ruminantes no Brasil. Pesquisa Veterinária Brasileira, Seropédica, v. 33, n. 2, p. 127-140, 2013.

ZAR, J. H. Biostatistical analysis. $4^{\text {th }}$ ed. Upper Saddle River: Prentice Hall, 1999. 663 p. 
